\title{
Process Evaluation of Decontamination, Cleaning and Sterilization of medical instruments at public health centers of Mekelle zone, Tigray, Ethiopia, 2018
}

Byin Tewolde Gebremichael ( $\square$ byin.tewolde@gmail.com )

Mekelle University https://orcid.org/0000-0002-9790-1862

Alem Desta Wuneh

Mekelle University

Mengistu Mitiku Ashebr

Mekelle University

Research article

Keywords: Decontamination, Cleaning, Sterilization, Health care workers and medical instruments

Posted Date: September 27th, 2019

DOl: https://doi.org/10.21203/rs.2.15493/v1

License: (c) (1) This work is licensed under a Creative Commons Attribution 4.0 International License.

Read Full License 


\section{Process Evaluation of Decontamination, Cleaning and Sterilization of Medical Instruments at Public Health Centers of Mekelle Zone, Tigray, Ethiopia, 2018}

Byin Tewolde $^{1}$, Alem Desta $^{2 *}$ and Mengistu Mitiku ${ }^{2}$

Mekelle University, College of Health Sciences, School of Public Health, Department of Health Service Management, Ethiopia

\footnotetext{
${ }^{1}$ Ayder Comprehensive Specialized Hospital, Mekelle University, Mekelle, Ethiopia

${ }^{2}$ Department of Health Service Management, School of Public Health, Mekelle University, Mekelle, Ethiopia
}

*Corresponding Authors

Email Addresses:

BT: byin.tewolde@gmail.com

AD: $\underline{\text { alemdw@gmail.com }}$

MM: mengistu.mitiku@yahoo.com 


\begin{abstract}
Background: Today Health Care Associated Infections are the major public health problems in majority of developing world including Ethiopia. The use of disposable equipment is the best way to ensure patient comfort and security, however, low income country health system could not acquire disposable format for certain devices due to the cost. Then some instruments need to be sterilized for re-use. In this study we have evaluated the sterilization status of medical instruments.
\end{abstract}

Method: Descriptive study design was employed in this evaluation study. The evaluation was conducted in 147 health care workers and nine public health centers of Mekelle zone from January to June, 2017. Systematic random sampling method was conducted to select study participants. In the quantitative part, observation of health care workers' practice and availability of materials were conducted using checklists. As a complement, key informant interviews were also conducted. Collected quantitative data were checked, coded and entered into SPSS version 20 for analysis. Frequencies Mean, percentage, tables were used for results presentation.

Result: Availability, compliance and safety of health care workers' dimensions were used to evaluate the implementation of the intervention. Accordingly, availability of resources in the studied health centers has been rated as good (74.2\%). And compliance level of health care workers has found to be fair $(66.1 \%)$. However, practice of safety by the health care workers has found to be poor (48\%).

Conclusion: According the judgment criteria, the overall implementation status of decontamination, cleaning and sterilization service has been rated as fair (63.4\%).

Key Words: Decontamination, Cleaning, Sterilization, Health care workers and medical instruments. 


\section{Introduction}

Health care associated infections (HCAI) are a major public health concern throughout the world, contributing to increased morbidity, mortality, and cost (1). It is a major safety issue affecting the quality of care of hundreds of millions of patients every year in both developed and developing countries (2). According to the World Health Organization (WHO) review, health facility-wide prevalence of health care-associated infections varies from $5.7 \%$ to $19.1 \%$, with a pooled prevalence of $10.1 \%$ in low-income countries (3). Recent studies suggest that the burden of HCAIs may be disproportionally high in resource-limited settings with rates of HCAIs estimated to be 2-20 times that of developed countries (4), (5).

In developing countries, the problem is three times higher when compared to the incidence observed in patient care units in the United States America (6). Today infection in healthcare facilities is a major public health problem in majority of developing world including Ethiopia. In Ethiopia HCAIs are major problems that need attention and action to improve the health institution infection prevention practices. Hence, in Ethiopia in general the problem of HCAIs related to poor infection prevention including improper decontamination, cleaning and sterilization of medical equipment are common in health care facilities (7).

Preventing HCAI is then a major objective for health facilities that aimed at providing safe health care to patients. The use of disposable equipment is the best way to ensure patient comfort and security. However, low income country health system could not acquire disposable format for certain devices due to the cost. Then some instruments need to be sterilized for re-use (8). Proper decontamination, cleaning and sterilization of medical equipment and other items that have contact with patient's body or their body fluid is the main and critical method in preventing and reducing the transmission of HCAIs and their impacts in health facilities during medical procedures and patient care (9).

The purpose of this evaluation was to provide clear and scientific information about the implementation status of the one and main part of infection prevention called decontamination, cleaning and sterilization of medical equipment in Mekelle zone health centers to stakeholders and then the findings will be used as a base line data for further studies. The objective of this evaluation research was to assess the implementation status of decontaminating, cleaning and sterilizing process of medical instruments in Mekelle zone health centers, Tigray-Ethiopia, 2017. 


\section{Methods and Materials}

This evaluation study was conducted in nine health centers and 147 health care workers using descriptive study design with mixed method approach in Mekelle zone from January to May, 2017.Proportional allocation was done to each health center and profession according to the number of health care workers they have. Then using simple random sampling HCWs were selected from each health center and profession. English version observational check lists was used to check the practices' of HCWs following the standard. In the quantitative part, observation of health care workers' practice and availability of materials were conducted using checklists. Data was entered and cleaned using EPI Info and analysis was done using SPSS version 20.As a complement, key informant interviews were also conducted. Frequencies, Mean, percentage and tables were used for quantitative results presentation and qualitative data were coded, categorized and finally conceptualized.

Evaluation proposal was first approved by Mekelle University College of health science, School of Public health Ethical review committee. Following this written permission was given to Tigray regional health bureau and the bureau also given written permission for each health centers. In addition to this informed consent was obtained from the health centers and HCWs prior to observing the practices and availability of materials. Their participation was voluntarily and they can be free to decline or withdraw at any time in the course of the study, so only those willing to participate were included in the study. Confidentiality was kept by making the checklists anonymous and no personal identifiers were used.

\section{Results}

\subsection{Quantitative results Socio-demographic characteristics of participants}

This evaluation research was conducted in 9 public health centers of Mekelle zone. All those health centers were financed by Tigray health bureau proportionally. A total of 147 HCWs were observed their practices during decontamination, cleaning and sterilization of medical instruments and their safety during the process. From the total participants, majority $(72.8 \%)$ were females. The age of participants ranged from 23-57 years with mean of 39 $( \pm 7)$.Regarding their profession, $76.9 \%$ participants were nurses and the rest $23.1 \%$ were midwives and laboratory personnel. Regarding their service year, 71.3\% HCWs had served for more than 10 years in their respective profession. 


\subsubsection{Availability of resources}

All health centers were assessed for the availability of basic supplies and equipment needed for decontamination, cleaning and sterilization process and safety of HCWs during the process. Based on this, all (9) health centers had functional autoclaves, bleach, detergent, brush, face masks, protective garment (apron), sterilization unit and gloves. Only 3 health centers had both national IP guideline and trained man power. Seven HCs had both eye wear/goggle and protective shoes. However, all (9) HCs had no indicators and procedure flow charts posted on the wall of the working area during the data collection period. Generally, the overall availability of resources was $74.2 \%$.

\subsubsection{Compliance of the health care workers with the national guideline}

Observation was conducted for $147 \mathrm{HCWs}$ for their practices in decontamination, cleaning and sterilization process of medical instruments in comparison with the national guideline. From the total HCWs, 128 (87.1\%) had used vapor sterilization (Autoclave) and 19 (12.9\%) used high level chemical disinfection (HLD). Of the 128 HCWs who used Autoclave, 38 (25.9\%) HCWs had used cotton wrapping and 90 (74.1\%) were used either drums or sets for instruments going to be sterilized. Among the HCWs who had used cotton wrapping, 29 (76.3\%) were used double layer of wrapping and the rest 9 (23.7\%) were used single layer of wrapping.

Among the total participants, 79 (53.7\%) HCWs processed soiled and clean instruments in the same work area and $68(46.3 \%)$ HCWs processed in the same room, but separate areas. All (100\%) HCWs decontaminated soiled instruments before cleaning using chlorine solution. Almost all 137 (93.2\%) HCWs prepared chlorine solution for by diluting 1 part of chlorine 5\% with 9 parts of water. Only 23 (15.6\%) HCWs immersed soiled instruments in chlorine solution for 10 minutes, the rest 124 (84.4\%) had immersed either for less than 10 minutes or more than 10 minutes.

None of the health workers had used indicator to monitor the success of sterilization process during the data collection time. Regarding labeling with sterilization date, 107 (72.8\%) HCWs had used labeling for sterilized medical instruments. And, only 48 (32.7\%) HCWs had withdrawn oldest sterile packs from the storage to use according to their date of sterilization (first sterilized first used). From the total participants, 97 (66\%) HCWs had monitored time during sterilization and $100 \% \mathrm{HCWs}$ had monitored pressure and temperature of the 
autoclave, though these were adjusted permanently. Thus, the overall compliance level of HCWs was $66.1 \%$.

\subsubsection{Safety of health care workers}

In this evaluation study, $147 \mathrm{HCWs}$ were observed for their proper selection and use of personal protective equipment during processing medical instruments. Thus, all $100 \% \mathrm{HCWs}$ had worn gloves. Similarly, 60 (40\%) HCWs had worn protective garment and 14 (9.2\%) HCWs had worn face mask. In general, the overall safety practices of HCWs during decontamination, cleaning and sterilization of medical instruments was $48 \%$.

\subsection{Qualitative result}

\section{Key informant interview}

Majority of the key informants described decontamination, cleaning and sterilization of medical instruments including safety of $\mathrm{HCWs}$, as it is the immersion of contaminated medical instruments (contamination is either during procedures or long time shelf life) in $0.5 \%$ chlorine solution for 10 minutes then washing using detergents and brushes, drying by using air then sterilize and ready them for the next procedure. They said also when they do this process it is important that using of PPE materials to prevent them from exposure to different potentially infectious substances. Following the description they listed the following resources as inputs for decontamination, cleaning and sterilization. These were; Autoclave, detergents, bleach, trained man power, guidelines, indicators, brushes, goggle, boots, apron, disposable gloves, water and face masks.

Most interviewers show the reasons for shortage of resources as a result of no focus for the service starting from TRHB in giving training, supporting of guidelines, flow charts and indicators. On the other hand there is trained staff turnover and assigning of trained staff in other activities. In case of guidelines there is a problem of simply storing in the environmental health office without any use. Here the HCWs have also their weakness in communicating the environmental health personnel to use the guideline. Regarding the poor compliances level of HCWs, most key informants said lack of resources like trained man power, IP guidelines, procedure flow charts, indicators and some safety equipment and lack of follow up from responsible bodies. The other reason is TRHB recommendation, example, the bureau recommended that all health centers should avoid any procedure flow chart including decontamination, cleaning and sterilization to maintain the color of the health 
center. In case of safety mostly it is carelessness and this is evidenced by one interviewer as follows.

"I think this arises from our weakness not availability and other institutional problems, because we don't care ourselves to care others. Let's tell you the truth please look the cabinet and the shelves they are full of PPE materials, but we are not committed to use them. Based on this the solution is already simple we should have use them for the future".

All the interviewers recommend that TRHB and other responsible bodies should be given focus for the service, give training for the HCWs and should support resources like updated guidelines, indicators, procedure flow charts and others.

\section{Discussion}

In general, the implementation status of decontamination, cleaning and sterilization process in public health centers of Mekelle zone has found to be fair (63.4\%). When disaggregated by dimension, the overall availability of resources has been rated good (74.2\%). Regarding the compliance level of HCWs, it was judged as fair (66.1\%). However, the overall safety of HCWs during decontamination, cleaning and sterilization was judged as poor (48\%).

\subsection{Availability of resources}

The overall finding of availability dimension has found to be good (74.2\%) when computed against the preset judgment standards. In this evaluation study, our findings showed that all (9) HCs had Autoclaves, Chlorine solution, Detergents, Sterilization unit, Gloves, Face mask, Protective garment/Apron, water access and brushes. On the other hand 7 health centers had both eye shields and protective shoes. According to the judgment criteria, this result was rated as good. The reason majority of interviewers mentioned for why not $100 \%$ was due to loss of focus for the service and no communications between the HCWs and other responsible bodies. This low availability of eye goggle and protective shoes contributes in increasing the risk of exposure to potentially infectious agents during decontamination, cleaning and sterilization process.

Health centers which had both written IP guideline and trained man power were only 3 . According the judgment criteria and the national guideline it was rated poor. This poor availability of trained man power was lower than a study finding in Benin (54.9\%) (8). As evidenced by one key informant interviewer, these differences were due to no continuous training is given, trained staff turnover and assigning of trained staffs in other duties. In 
addition to this the reasons for the shortage of written IP guidelines is due to simply stored in the environmental health offices and other units out of the decontamination, cleaning and sterilization areas. This shortage of written guidelines and trained manpower makes decontamination, cleaning and sterilization practice not conform to the standards and this leads HCWs to practice by guess. One key informant quoted out the reasons for the above shortages of resources as follows.

"We are working simply from previous experiences, because there are no IP guidelines and IP training. These shortages of resources can lead HCWs to decontaminate, cleaning and sterilizing medical instruments by guess and as a result of this there may be ineffectively sterilized medical instruments and then continue to increase the health care associated infections."

Decontamination, cleaning and sterilization flow chart has a crucial role to help HCWs when they are confusing during any step of decontamination, cleaning and sterilization. However, there was no health center with flow charts posted on the wall of the decontamination, cleaning and sterilization unit. Similarly, there was no health center which had indicators to see the success of sterilization process. This finding was lower than study finding in Bahirdar city which was $11.1 \%$ (7). This difference might be due to loss of focus for the service. Absence of these resources may cause ineffective decontamination, cleaning and sterilization process of medical instruments. The reasons for the absence of these resources are evidenced by one key informant as follows;

"In my working time in this health center, I have never seen and use any indicator during sterilization and I have no any information why it is absent. In case of decontamination, cleaning and sterilization flow chart, we have been removed from the wall of working areas because of the order of TRHB. The reason for removal is to maintain the beauty of the health center".

\subsection{Compliance with the national guideline}

This evaluation study found that the overall result for compliance was rated fair (66.1\%). There were excellent practices of HCWs observed in decontaminating soiled instruments prior to cleaning and sterilization and monitoring of pressure as well as temperature during sterilization. Similarly, 93\% HCWs were prepared chlorine solution according to the national guideline which is 1 part of chlorine solution with 9 parts of water. This finding is slightly lower than the study finding in Bahir-dar city (100\%) (7). This 7\% declining in compliance level of HCWs during preparing chlorine solution was comes from laboratory personnel. 
Regarding, the drying status of instruments after removal from the autoclave, it was very good $88 \%$. When we see number of layers used to wrap clean instruments going to be sterilized, 76\% (29/38) HCWs used two layers of cotton wrap. Ideally, two layers of wrapping material are recommended, as there are frequently small tears in individual layers. A second layer will prevent instruments from contamination before use, and two layers are thin enough to allow steam to penetrate and sterilize the item (10). Based on this idea it was a good practice of wrapping during sterilization.

Regarding labeling of medical instruments with sterile date after sterilization, $72 \% \mathrm{HCWs}$ were did it which was good. This finding is better than a study conducted in Bahir-dar city (25\%) (7). Time monitoring during sterilization is very important, but this study found that only $71 \% \mathrm{HCWs}$ were monitored the correct time. As a result this may cause ineffective sterilization process of medical instruments.

Clean and contaminated instruments must be separated, ideally into different rooms, because it reduces the risks of contaminating or confusing clean instruments with soiled ones (10), so this study found that $46 \% \mathrm{HCWs}$ were used separate rooms for soiled and clean instruments during processing. According the judgment criteria this was judged as poor practice. This may increase the risk of cross-contamination of each other and confusing HCWs in differentiating clean from contaminated instruments. In this study the other poor practice of HCWs was, using oldest packs first which was only 32\%. On the other hand only $15.3 \%$ HCWs were immersed contaminated instruments in $0.5 \%$ chlorine solution for 10 minutes. The rest $84.7 \%$ HCWs immersed either for less than 10 minutes or more than 10 minutes. This showed that there was big difference with the national guideline, because contaminated items should be immersed for 10 minutes prior to cleaning (9). If the duration of immersion is less than 10 minutes, it causes ineffective sterilization of instruments and if it is greater than 60 minutes, it causes rest of the instruments.

In this study there was no HCW used indicator during sterilization of medical instruments. This is completely wrong according to the national guideline. This might be due to no availability of indicators in the health centers. The reasons and possible solutions were quoted by one interviewer as follows.

"As my stand the reasons for poor compliances level of HCWs are carelessness from the HCWs themselves in the service, shortage of trainings, IP guidelines and even no flow charts and indicators. So to solve this problem HCWs, TRHB and other responsible bodies should 
be given focus for the service, train the HCWs and should support resources like updated guidelines, indicators, procedure flow charts and others".

\subsection{Safety of health care workers}

Personal Protective Equipment (PPE) protects HCWs by creating a barrier between the person and any potentially infectious substance (11). This study tried to assess the proper selection and use of PPE by HCWs during decontamination, cleaning and sterilization process. Thus, the overall finding of safety in HCWs in Mekelle zone public health centers was poor $(48 \%)$. When we see each practice, $100 \% \mathrm{HCW}$ were worn disposable gloves during decontamination, cleaning and sterilization of medical instruments. This finding is higher than studies done in Bahir-dar city 73.4\% (7). Possible justification could be due to time gap, increasing the awareness and attitude of HCWs on infection prevention.

Regarding protective garment/apron $41 \%$ HCWs were worn it during decontamination, cleaning and sterilization of medical instruments. According the judgment criteria and national guideline it was poor practice, but when we compare with the study finding conducted in Bahir-dar city (10\%), it was increased. This might be due to professional differences of study participants and increased awareness of the HCWs with the time gap.

Other poor practices of HCWs in using PPE during decontamination, cleaning and sterilization of medical instruments were face mask, eye shields and protective shoes which were $9.6 \%, 8 \%$ and $4 \%$ respectively. Those results were much lower than the national guideline. On the other hand this finding is lower than a research findings conducted in Bahir-dar city which was $12 \%$ for face mask, $10.6 \%$ for protective shoes and $9.4 \%$ for eye goggle. These poor practices of HCWs in using PPE may increase the risk of exposure to different health hazards. One key informant gave his witness for this issue as the following quotation.

"I think this is arises from our weakness not availability and other organizational problems, because we don't care ourselves to care others. Let's tell you the truth please look the cabinet and the shelves they are full of PPE materials, but we are not committed to use them. Based on this the solution is already simple we should have use them for the future". 


\section{Conclusion}

Based on the judgment parameters developed after discussion has been conducted with the key stakeholders, the overall implementation status of the service was rated fair (63.4\%).Regarding each dimension, the result for availability dimension found to be good (74.2\%) and compliance dimension was rated fair (66.1\%). However, the overall Safety of HCWs was rated poor $(48 \%)$.

\section{Acknowledgement}

My appreciation and heartiest gratitude goes to my advisor Mr. Alem Desta and my coadviser Mr. Mengistu Mitiku for their inspiring collective leadership, constructive and helpful suggestions, comments, advice and supports throughout the research.

At last I would like to thanks to my family members for their support throughout my master program.

\section{Abbreviations}

HC: Health Center; HCAI: Health Care Associated Infection; HCW: Health Care Workers; HLD: High Level Disinfection; IP: Infection Prevention; PPE: Personal Protective Equipment; WHO: World Health Organization.

\section{Authors' Contribution}

BT: Was Contributing in title selection, doing the Evaluability Assessment, Developing the proposal and indicators, Collecting and analyzing data; AD: was supporting me in detail, especially during the indicator development; MM: Was help me in the general structure of the research.

\section{Competing Interests}

No Competing interest 


\section{References}

1. Geffers C GP. Nosocomial infections and multidrug-resistant organisms in Germany. 2011;6:87-93.

2. Allegranzi B SJ, Dziekan G, Leotsakos A, Donaldson L, Pittet D. . The first global patient safety challenge "clean care is safer care": from launch to current progress and achievements. 2007:115-23.

3. WHO. Report on the Burden of Endemic Health Care-Associated Infection Worldwide. 2011.

4. Laurie R CK. Understanding the Central Sterile Use Environment and Reprocessing Challenges. International Symposium on Human Factors and Ergonomics in Health Care. 2014:3.

5. TMOH. Infection prevention and control policies and guidelines for health care services. Pan American Health Organization. 2011:1.

6. Allegranzi B BNS, Combescure C, et al. . Burden of endemic health-care-associated infection in developing countries: systematic review and meta-analysis. 2011:228-41.

7. Kelemua G GT. Assessment of knowledge, attitude and practice of health care workers on infection prevention. Science Journal of Public Health. 2014:2.

8. Edgard. M. Evaluation of the Quality of Medico-technical equipment Sterilization. The Open Public Health Journal. 2016:1.

9. EMOH. Infection prevention and patient safety management training for healthcare facility managers manual. 2012

10. USAID. Infection Control Assessment Tool for Primary Health Care Facilities. System for improved access to pharmaceutical and service. 2013.

11. Ethiopian Hospital Reform Implementation Guidelines. Ethiopian Federal ministry of health 2010;1:333. 


\section{List of Tables}

Table 1: Relevant matrix with its judgment criteria for decontamination, cleaning and sterilization of medical instruments at public health centers of Mekelle zone, Tigray-Ethiopia, 2017

\begin{tabular}{|c|c|c|c|c|c|c|}
\hline Dimensions & $\begin{array}{l}\text { Number of } \\
\text { indicators }\end{array}$ & $\begin{array}{l}\text { Recom } \\
\text { mended }\end{array}$ & $\begin{array}{l}\text { Achiev } \\
\text { ed }\end{array}$ & Weight & $\begin{array}{l}\text { Result } \\
\text { in } \%\end{array}$ & $\begin{array}{l}\text { Judgment criteria for } \\
\text { each dimension and } \\
\text { indicator }\end{array}$ \\
\hline Availability of resources & 15 & 100 & & 35 & & \multirow{4}{*}{$\begin{array}{l}>90 \%=\text { Excellent } \\
81-90 \%=\text { Very good } \\
70-80 \%=\text { Good } \\
60-69 \%=\text { Fair and } \\
<60 \%=\text { Poor }\end{array}$} \\
\hline Compliance & 12 & 100 & & 35 & & \\
\hline Safety of HCWs & 5 & 100 & & 30 & & \\
\hline Total & 32 & 100 & & 100 & & \\
\hline
\end{tabular}

Table 2: Participants' Socio-Demographic characteristics of participants at public health centers of Mekell zone, Tigray-Ethiopia, 2017

\begin{tabular}{|l|c|c|}
\hline Variables & Frequencies & Percentage (\%) \\
\hline Sex & & \\
\hline Female & 107 & 72.8 \\
\hline Male & 40 & 27.2 \\
\hline Total & 147 & 100 \\
\hline Profession & & \\
\hline Nurse & 113 & 76.9 \\
\hline Midwife & 23 & 15.6 \\
\hline Laboratory personnel & 11 & 7.5 \\
\hline Total & 147 & 100 \\
\hline
\end{tabular}


Table 3: Availability of medical supplies and equipment for decontamination, cleaning and sterilization of medical instruments at public health centers of Mekelle zone, Tigray-Ethiopia, 2017

\begin{tabular}{|c|c|c|c|c|c|c|c|c|c|c|c|c|c|c|c|c|c|c|c|}
\hline \multirow{2}{*}{$\begin{array}{l}\text { Supplies and } \\
\text { equipment }\end{array}$} & \multicolumn{2}{|c|}{$\mathrm{HC} 1$} & \multicolumn{2}{|c|}{$\mathrm{HC} 2$} & \multicolumn{2}{|c|}{$\mathrm{HC} 3$} & \multicolumn{2}{|c|}{$\mathrm{HC} 4$} & \multicolumn{2}{|c|}{ HC5 } & \multicolumn{2}{|c|}{ HC6 } & \multicolumn{2}{|c|}{$\mathrm{HC} 7$} & \multicolumn{2}{|c|}{$\mathrm{HC} 8$} & \multicolumn{2}{|c|}{ HC9 } & \multirow{2}{*}{$\begin{array}{l}\text { Total } \\
\text { HCs } \\
\text { with }\end{array}$} \\
\hline & $\mathrm{Y}$ & $\mathrm{N}$ & $\mathrm{Y}$ & $\mathrm{N}$ & $\mathrm{Y}$ & $\mathrm{N}$ & $\mathrm{Y}$ & $\mathrm{N}$ & $\mathrm{Y}$ & $\mathrm{N}$ & $\mathrm{Y}$ & $\mathrm{N}$ & $\mathrm{Y}$ & $\mathrm{N}$ & $\mathrm{Y}$ & $\mathrm{N}$ & $\mathrm{Y}$ & $\mathrm{N}$ & \\
\hline Autoclave & $\mathrm{x}$ & & $\mathrm{x}$ & & $\mathrm{X}$ & & $\mathrm{x}$ & & $\mathrm{x}$ & & $\mathrm{x}$ & & $\mathrm{x}$ & & $\mathrm{x}$ & & $\mathrm{X}$ & & 9 \\
\hline Sterilization unit & $\mathrm{x}$ & & $\mathrm{x}$ & & $\mathrm{X}$ & & $\mathrm{x}$ & & $\mathrm{x}$ & & $\mathrm{x}$ & & $\mathrm{x}$ & & $\mathrm{x}$ & & $\mathrm{x}$ & & 9 \\
\hline Disposable glove & $\mathrm{x}$ & & $\mathrm{x}$ & & $\mathrm{X}$ & & $\mathrm{x}$ & & $\mathrm{x}$ & & $\mathrm{x}$ & & $\mathrm{x}$ & & $\mathrm{x}$ & & $\mathrm{x}$ & & 9 \\
\hline IP guideline & $\mathrm{x}$ & & & $\mathrm{x}$ & & $\mathrm{X}$ & & $\mathrm{X}$ & & $\mathrm{x}$ & & $\mathrm{x}$ & & $\mathrm{x}$ & $\mathrm{x}$ & & $\mathrm{X}$ & & 3 \\
\hline Procedure flow charts & & $\mathrm{x}$ & & $\mathrm{x}$ & & $\mathrm{x}$ & & $\mathrm{x}$ & & $\mathrm{x}$ & & $\mathrm{x}$ & & $\mathrm{x}$ & & $\mathrm{x}$ & & $\mathrm{x}$ & 0 \\
\hline Brushes & $\mathrm{x}$ & & $\mathrm{x}$ & & $\mathrm{X}$ & & $\mathrm{x}$ & & $\mathrm{x}$ & & $\mathrm{x}$ & & $\mathrm{x}$ & & $\mathrm{x}$ & & $\mathrm{X}$ & & 9 \\
\hline Protective shoes & $\mathrm{x}$ & & & $\mathrm{x}$ & $\mathrm{x}$ & & $\mathrm{x}$ & & & $\mathrm{x}$ & $\mathrm{x}$ & & $\mathrm{x}$ & & $\mathrm{x}$ & & $\mathrm{x}$ & & 7 \\
\hline Detergent & $\mathrm{x}$ & & $\mathrm{x}$ & & $\mathrm{x}$ & & $\mathrm{x}$ & & $\mathrm{x}$ & & $\mathrm{x}$ & & $\mathrm{x}$ & & $\mathrm{x}$ & & $\mathrm{x}$ & & 9 \\
\hline Trained man power & $\mathrm{x}$ & & & $\mathrm{x}$ & & $\mathrm{x}$ & $\mathrm{x}$ & & & $\mathrm{x}$ & & $\mathrm{x}$ & & $\mathrm{x}$ & $\mathrm{x}$ & & & $\mathrm{x}$ & 3 \\
\hline Face mask & $\mathrm{x}$ & & $\mathrm{x}$ & & $\mathrm{x}$ & & $\mathrm{x}$ & & $\mathrm{x}$ & & $\mathrm{x}$ & & $\mathrm{x}$ & & $\mathrm{x}$ & & $\mathrm{x}$ & & 9 \\
\hline $\begin{array}{l}\text { Protective } \\
\text { garment/Apron }\end{array}$ & $\mathrm{x}$ & & $\mathrm{x}$ & & $\mathrm{X}$ & & $\mathrm{x}$ & & $\mathrm{X}$ & & $\mathrm{x}$ & & $\mathrm{X}$ & & $\mathrm{x}$ & & $\mathrm{X}$ & & 9 \\
\hline Bleach & $\mathrm{x}$ & & $\mathrm{x}$ & & $\mathrm{X}$ & & $\mathrm{x}$ & & $\mathrm{X}$ & & $\mathrm{x}$ & & $\mathrm{x}$ & & $\mathrm{x}$ & & $\mathrm{x}$ & & 9 \\
\hline Eye goggle & $\mathrm{x}$ & & & $\mathrm{x}$ & $\mathrm{X}$ & & $\mathrm{x}$ & & $\mathrm{x}$ & & $\mathrm{x}$ & & $\mathrm{x}$ & & & $\mathrm{x}$ & $\mathrm{x}$ & & 7 \\
\hline Indicators & & $\mathrm{x}$ & & $\mathrm{x}$ & & $\mathrm{X}$ & & $\mathrm{X}$ & & $\mathrm{x}$ & & $\mathrm{x}$ & & $\mathrm{x}$ & & $\mathrm{x}$ & & $\mathrm{x}$ & 0 \\
\hline Water access & $\mathrm{x}$ & & $\mathrm{x}$ & & $\mathrm{X}$ & & $\mathrm{x}$ & & $\mathrm{x}$ & & $\mathrm{x}$ & & $\mathrm{X}$ & & $\mathrm{X}$ & & $\mathrm{X}$ & & 9 \\
\hline
\end{tabular}

NB: $\mathrm{Y}=\mathrm{Yes}, \mathrm{N}=\mathrm{No}$ 
Table 4: Matrix of judgment for availability of resources required for decontamination, cleaning and sterilization of medical instruments at public health centers of Mekelle zone,

Tigray-Ethiopia, 2017

\begin{tabular}{|l|l|l|l|l|l|l|}
\hline \multicolumn{1}{|c|}{ Indicators } & $\begin{array}{l}\text { Expe } \\
\text { cted }\end{array}$ & $\begin{array}{l}\text { Achie } \\
\text { ved }\end{array}$ & $\begin{array}{l}\text { Wei } \\
\text { ght }\end{array}$ & $\begin{array}{l}\text { Result } \\
\text { in } \%\end{array}$ & $\begin{array}{l}\text { Judgme } \\
\text { nt }\end{array}$ \\
\hline $\begin{array}{l}\text { Number of HCs with infection prevention guideline contains } \\
\text { cleaning and sterilization section }\end{array}$ & 9 & 3 & 5 & 1.6 & 34 & Poor \\
\hline $\begin{array}{l}\text { Number of HCs with at least one trained HCW on } \\
\text { decontamination, cleaning and sterilization procedures }\end{array}$ & 9 & 3 & 15 & 5 & 33.3 & Poor \\
\hline $\begin{array}{l}\text { Number of HCs with cleaning and sterilization flow chart posted } \\
\text { on the wall of sterilization unit }\end{array}$ & 9 & 0 & 5 & 0 & 0 & Poor \\
\hline Number of HCs with functional Autoclave/sterilizer & 9 & 9 & 10 & 10 & 100 & Excellent \\
\hline $\begin{array}{l}\text { Number of HCs which had chlorine for cleaning and sterilizing } \\
\text { of medical instruments }\end{array}$ & 9 & 9 & 10 & 10 & 100 & Excellent \\
\hline $\begin{array}{l}\text { Number of HCs which had detergent for cleaning and sterilizing } \\
\text { of medical instruments }\end{array}$ & 9 & 9 & 5 & 5 & 100 & Excellent \\
\hline Number of HCs which had sterilization indicators & 9 & 0 & 5 & 0 & 0.0 & Poor \\
\hline $\begin{array}{l}\text { Number of HCs with Eye goggle at the cleaning and sterilization } \\
\text { area }\end{array}$ & 9 & 7 & 5 & 3.8 & 76 & Good \\
\hline $\begin{array}{l}\text { Number of HCs with disposable gloves at the cleaning and } \\
\text { sterilization area }\end{array}$ & 9 & 9 & 5 & 5 & 100 & Excellent \\
\hline $\begin{array}{l}\text { Number of HCs with face mask at the cleaning and } \\
\text { sterilization area }\end{array}$ & 9 & 9 & 5 & 5 & 100 & Excellent \\
\hline $\begin{array}{l}\text { Number of HCs with protective foot wear at the cleaning and } \\
\text { sterilization area }\end{array}$ & 9 & 7 & 5 & 3.8 & 76 & Good \\
\hline $\begin{array}{l}\text { Number of HCs with protective garment at the cleaning and } \\
\text { sterilization area }\end{array}$ & 9 & 9 & 5 & 5 & 100 & Excellent \\
\hline Number of HCs which have sterilization unit & 9 & 9 & 5 & 5 & 100 & Excellent \\
\hline Number of HCs which has brush for scrubbing instruments & 9 & 9 & 5 & 5 & 100 & Excellent \\
\hline Number of HCs with water access & 9 & 9 & 10 & 10 & 100 & Excellent \\
\hline Over all Availability dimension & & & & & & \\
\hline
\end{tabular}


Table 5: Matrix of judgment for compliance of HCWs with the national guideline during decontamination, cleaning and sterilization of medical instruments at public health centers of Mekelle zone, Tigray-Ethiopia, 2017

\begin{tabular}{|c|c|c|c|c|c|c|}
\hline Indicators & Expe & $\begin{array}{l}\text { Achi } \\
\text { eved }\end{array}$ & \begin{tabular}{l|l} 
Wei \\
ght
\end{tabular} & $\begin{array}{l}\text { Resul } \\
t\end{array}$ & $\begin{array}{l}\text { Result } \\
\text { in \% }\end{array}$ & Judgment \\
\hline $\begin{array}{l}\text { Proportion of HCWs who separate soiled and clean items } \\
\text { from each other }\end{array}$ & 147 & 68 & 5 & 2.3 & 46 & Poor \\
\hline $\begin{array}{l}\text { Proportion of HCWs who decontaminate soiled } \\
\text { instruments before cleaning }\end{array}$ & 147 & 147 & 15 & 15 & 100 & Excellent \\
\hline $\begin{array}{l}\text { Proportion of HCWs who prepared } 1 \text { part of chlorine } \\
\text { with } 9 \text { parts of water }\end{array}$ & 147 & 137 & 10 & 9.3 & 93 & Excellent \\
\hline $\begin{array}{l}\text { Proportion of HCWs who immersed soiled instruments in } \\
\text { to chlorine solution for } 10 \mathrm{~min}\end{array}$ & 147 & 23 & 15 & 2.3 & 15.3 & Poor \\
\hline $\begin{array}{l}\text { Proportion of HCWs who used two layers of wrapping } \\
\text { for items to be sterilized }\end{array}$ & 38 & 29 & 5 & 3.8 & 76 & Good \\
\hline $\begin{array}{l}\text { Proportion of HCWs who monitored time during } \\
\text { sterilization }\end{array}$ & 147 & 104 & 10 & 7.1 & 71 & Good \\
\hline $\begin{array}{l}\text { Proportion of HCWs who monitored pressure during } \\
\text { sterilization }\end{array}$ & 128 & 128 & 10 & 10 & 100 & Excellent \\
\hline $\begin{array}{l}\text { Proportion of HCWs who monitored temperature during } \\
\text { sterilization }\end{array}$ & 128 & 128 & 10 & 10 & 100 & Excellent \\
\hline $\begin{array}{l}\text { Proportion of HCWs who used indicator to monitor the } \\
\text { success of sterilization }\end{array}$ & 147 & 0 & 5 & 0 & 0 & Poor \\
\hline $\begin{array}{l}\text { Proportion of HCWs who labeled sterile packs with the } \\
\text { date of sterilization }\end{array}$ & 147 & 107 & 5 & 3.6 & 72 & Good \\
\hline $\begin{array}{l}\text { Proportion of HCWs who used the oldest sterile packs } \\
\text { first }\end{array}$ & 147 & 48 & 5 & 1.6 & 32 & Poor \\
\hline $\begin{array}{l}\text { Proportion of HCWs who dried items after removal from } \\
\text { the autoclave }\end{array}$ & 128 & 112 & 5 & 4.4 & 88 & Very good \\
\hline \multicolumn{3}{|l|}{ Over all Compliance dimension } & 100 & 66.1 & 66.1 & Fair \\
\hline
\end{tabular}


Table 6: Matrix of judgment for safety of HCWs during decontamination, cleaning and sterilization of medical instruments at public health centers of Mekelle zone, Tigray-Ethiopia, 2017

\begin{tabular}{|l|l|l|l|l|l|l|}
\hline \multicolumn{1}{|c|}{ Indicators } & $\begin{array}{l}\text { Expe } \\
\text { cted }\end{array}$ & $\begin{array}{l}\text { Achie } \\
\text { ved }\end{array}$ & $\begin{array}{l}\text { Weig } \\
\text { ht }\end{array}$ & $\begin{array}{l}\text { weighte } \\
\text { d result }\end{array}$ & $\begin{array}{l}\text { Observe } \\
\text { d result } \\
\text { in } \%\end{array}$ & $\begin{array}{l}\text { Judgme } \\
\text { nt }\end{array}$ \\
\hline $\begin{array}{l}\text { Proportion of HCWs who wear disposable gloves } \\
\text { during cleaning and sterilizing of instruments }\end{array}$ & 147 & 147 & 40 & 40.0 & 100 & Excellent \\
\hline $\begin{array}{l}\text { Proportion of HCWs who wear facemask during } \\
\text { cleaning and sterilizing of instruments }\end{array}$ & 147 & 14 & 25 & 2.3 & 9.2 & Poor \\
\hline $\begin{array}{l}\text { Proportion of HCWs who wear protective eye } \\
\text { shields during cleaning and sterilizing of instruments }\end{array}$ & 147 & 12 & 20 & 1.6 & 8 & Poor \\
\hline $\begin{array}{l}\text { Proportion of HCWs who wear garment/apron } \\
\text { during cleaning and sterilizing of instruments }\end{array}$ & 147 & 60 & 10 & 4 & 40 & Poor \\
\hline $\begin{array}{l}\text { Proportion of HCWs who wear protective shoes } \\
\text { during cleaning and sterilizing of instruments }\end{array}$ & 147 & 6 & 5 & 0.2 & 4 & Poor \\
\hline Over all Safety dimension & & & 100 & 48 & 48 & Poor \\
\hline
\end{tabular}




\section{List of Figures}

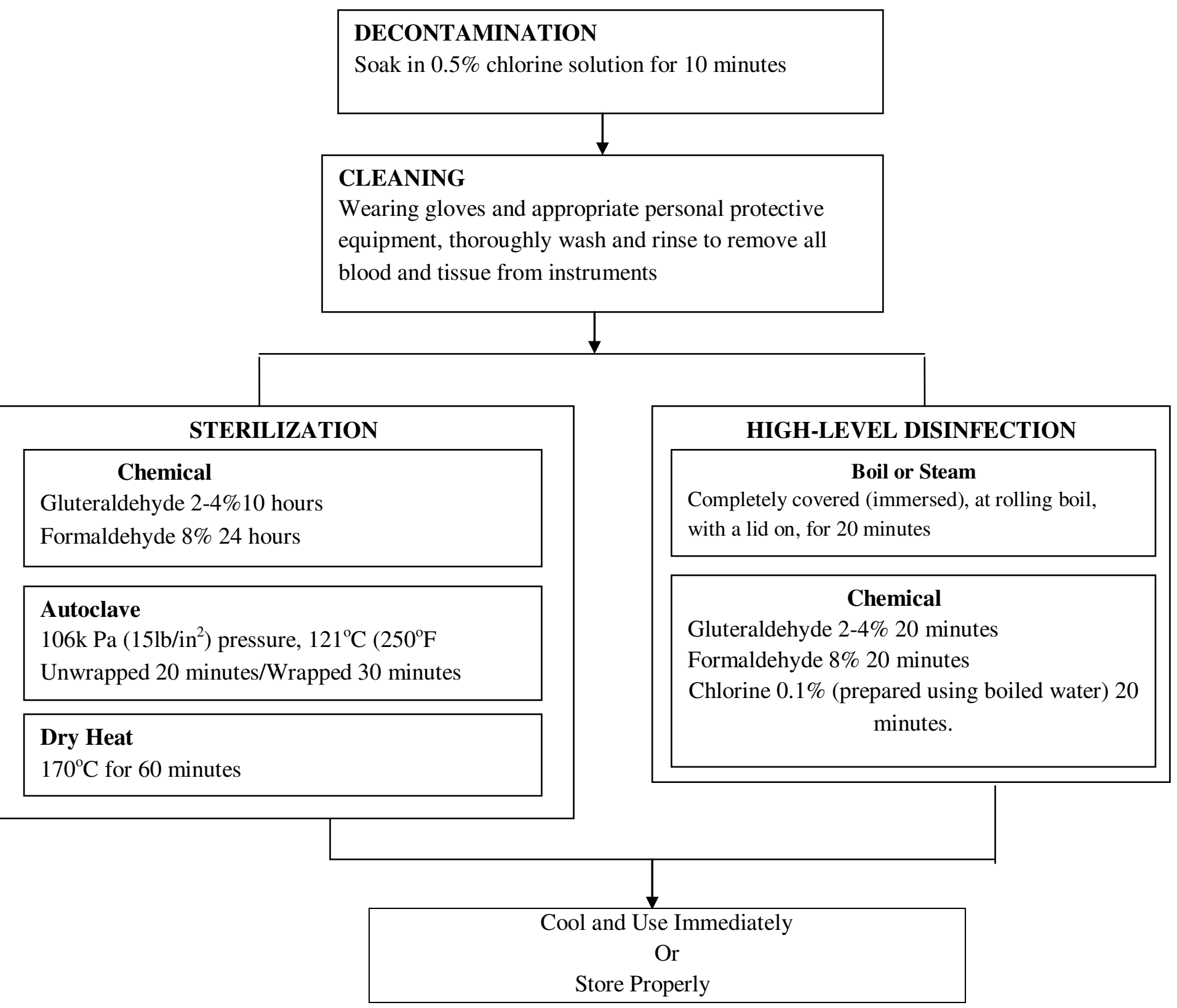

Figure 1: Key steps in decontamination, cleaning and sterilization of medical instruments, 2017

Source: MoH IP guideline (2012) 
Problem Identification: The burden of health care associated infections/HCAIs in health facilities forces to policy makers, program managers and health providers to develop infection prevention policies, strategies and interventions including decontamination, cleaning and sterilization of medical instruments.

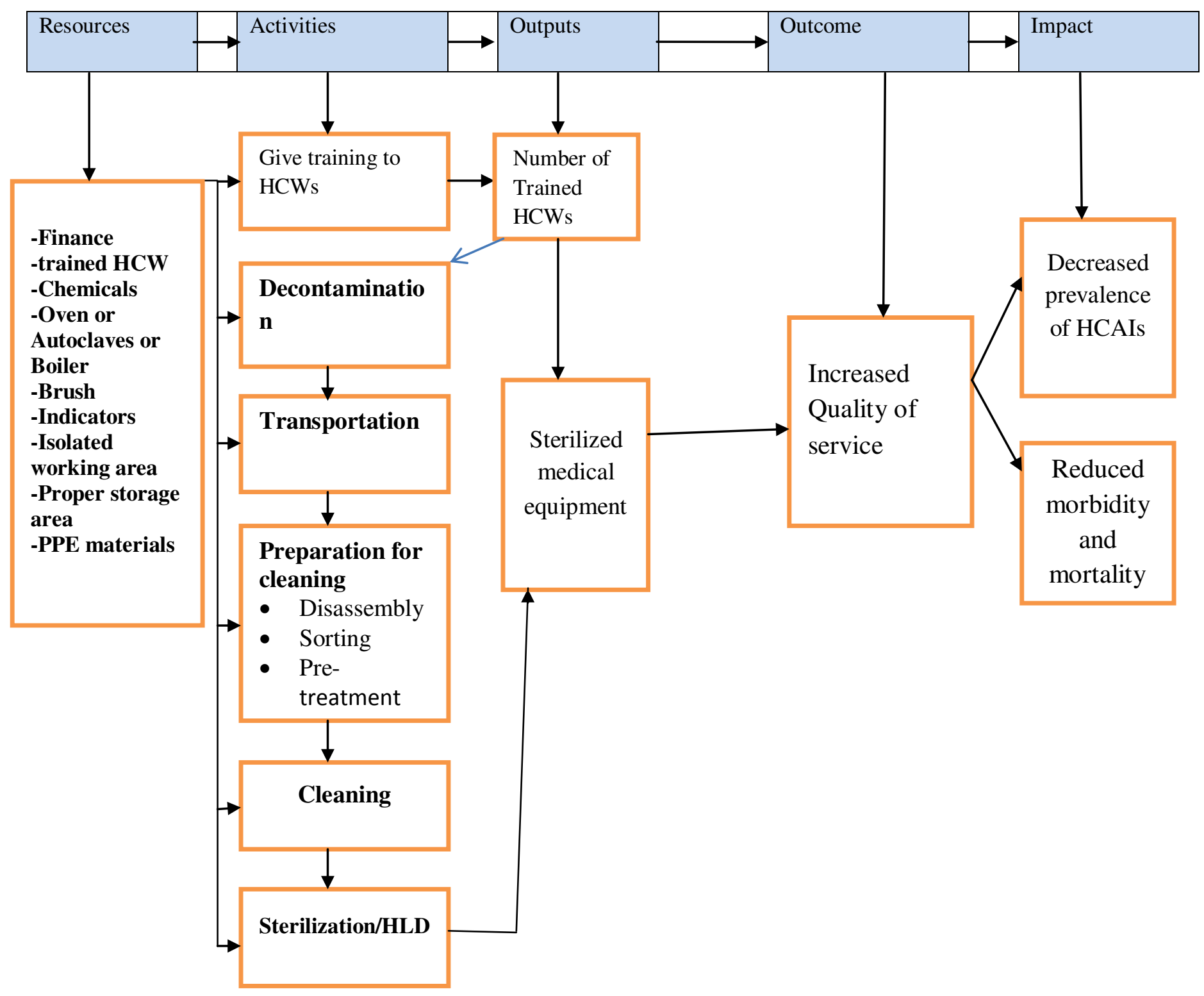

Figure 2: Logic model for decontamination, cleaning and sterilization of medical instruments at public health centers of Mekelle zone, Tigray-Ethiopia, 2017 